\title{
Employee's Attitude and Organizational Sustainability Performance: An Evidence From Jordan's Banking Sector
}

\author{
Firas A. Rifai ${ }^{1}$, Abdul Sattar H. Yousif ${ }^{1}$, Omar M. Bwaliez ${ }^{2}$, Moayyad Abdel-Razzaq Al-Fawaeer ${ }^{1}$ \& Bushra M. \\ Ramadan ${ }^{1}$ \\ ${ }^{1}$ Faculty of Business, Al-Zaytoonah University of Jordan, Amman, Jordan \\ ${ }^{2}$ School of Management and Logistics Sciences, German Jordanian University, Amman, Jordan \\ Correspondence: Moayyad Abdel-Razzaq Al-Fawaeer, Faculty of Business, Al-Zaytoonah University of Jordan, \\ Amman, Jordan.
}

Received: November 29, 2020

Accepted: December 23, 2020

Online Published: January 20, 2021

doi:10.5430/rwe.v12n2p166

URL: https://doi.org/10.5430/rwe.v12n2p166

\begin{abstract}
This study aims to investigate the role of employee's attitudes towards implementing and expanding the sustainability policy and the sustainability performance in terms of economic, social, and environmental dimensions. The study model and hypotheses were developed based on a comprehensive literature review. The data were collected from 84 employees working in Jordan's banking sector through a questionnaire. The results revealed that there is a significant and positive relationship between employee's attitudes towards implementing and expanding the sustainability policy and the triple bottom lines of sustainability performance. This study promotes the idea of focusing on employee's attitudes in the banking sector and others sectors in order to enhance sustainability performance, especially that sustainability still does not have the highest priority in a country with an emerging economy like Jordan. The results of the study have significant implications and open many avenues for future research.
\end{abstract}

Keywords: employee's attitude, sustainability, economic dimension, social dimension, environmental dimension, Jordan, banking sector

JEL Codes: M10, M14, D80

\section{Introduction}

Today, it is largely acknowledged that sustainability has to be considered in organization's corporate strategy development (Chang et al., 2018; Brömer et al., 2019). It is well known that sustainability promotes economic prosperity, increased social welfare, and environmental protection (Schaltegger, 2011; Schaltegger et al., 2012; Sharabati, 2018; Brömer et al., 2019). Adopting sustainability by an organization can influence not only its financial performance (Agyemang and Ansong, 2017), but also its reputation (Fatma et al., 2015; Agyemang and Ansong, 2017), and innovation (Shin et al., 2018). It is crucial for organizations to strive for sustainability because it provides the best ways to improve the lives of people everywhere. However, many organizations still face challenges to achieve sustainability (Abbasi and Nilsson, 2012; Merriman et al., 2016; Bhtta et al., 2020).

Although previous scholarly works have explored the role of organization's strategy, legal framework, industry norms, innovation, pollution prevention and the use of clean technologies to achieve sustainability (Farooq et al., 2019), they have paid little attention to the role of employees in implementing and expanding an organization's sustainability performance. According to Kucharska and Kowalczyk (2019), the employees are the organization. Therefore, the impact of employees on the successful implementation of organizational sustainability should not be neglected (Harmon and Moolenkamp 2012; Lee and Ha-Brookshire, 2018). The role of employees in any type of organization is very critical in achieving a successful implementation or expansion of any type of rules, procedures, policies, programs, and strategies (Hobson and Essex, 2001). Various recent studies confirmed the significant and positive effect of employee satisfaction, employee engagement, and employee attitude on business outcomes (Harmon and Moolenkamp, 2012; Anitha, 2014; Melián-González, 2016; Inuwa et al., 2017; Smith and Bititci, 2017; Upadhyay and Awasthi, 2020). In addition, Ray (2020) argued that attitudes and perspectives towards sustainability aspects "are not reflected as concerted effort". This study goes in line with these studies and proposes that employees' 
attitudes play a pivotal role in implementing and expanding sustainability policy adopted by the organization. Some employees are open to adopting the latest sustainability solutions because they see the opportunities this policy offer. Many other employees, in contrast, are reluctant to accept this policy and may even be frightened by it.

With a history of dating back to 1948, Jordan's banking sector is one of the largest and strongest economic sectors in the kingdom (ABJ, 2020). Due to its high economic relevance and its exposure to increasing sustainability requirements, the banking sector in Jordan was chosen as an empirical research field. There are many previous studies that have addressed the extent to which sustainability dimensions are applied in various Jordanian sectors, such as hotel industry (Al Qeed, 2015), mobile telecommunications (Obeidat, 2016), and pharmaceutical industry (Sharabati, 2018). However, Jordanian academics and practitioners still have no enough insight if the banking sector is moving toward sustainability or not, and how to improve sustainability in such vital sector (Masa'deh et al., 2018). Hence, one of the main motivations for conducting this study is that it is one of the first studies that create awareness about the adoption of sustainability by the Jordanian banking sector, especially since sustainability is still not a top priority in Jordan. Moreover, the importance of this study is also highlighted through its contribution to presenting results that can show the many administrative impacts of the services sector in general and the banking sector in particular when adopting strategies that support the implementation of sustainability.

The remainder of this study is organized as follows: Section 2 presents an exhaustive review of relevant literature. Section 3 presents hypotheses development and the research model. Section 4 presents the research methodology. Results and discussions are presented in Section 5 and 6 respectively. Conclusions and implications are presented in Section 7. Finally, limitations and recommendations are presented in Section 8.

\section{Literature Review}

We examined the literature related to employee's attitude, sustainability and its dimensions to develop the theoretical background for this study.

\subsection{Employee's Attitude}

Despite the importance of education, experience, skills, training, and intelligence in assessing the effectiveness of an organization's employees, they are actually of less importance than that of employee's attitude, which can be considered the most influential factor of employee's performance and effectiveness (DeCenzo et al., 2016). Employee's attitude can be defined as the persistent tendency to feel and behave in a favorable or unfavorable way toward some objects, persons, and ideas (Bohner and Dickel, 2011; Anitha, 2014). Employee's attitude is a mental and neural state of readiness organized through experience. It exerts a directive or dynamic influence upon the individual's response to all objects and situations with which it is related (Igbaria et al., 1994). According to Ali and Sayyed (2012), employee's attitude is a hypothetical construct representing an employee's degree of like or dislike for an item, person, place, or event. Elias (2009) argued that employees' attitudes toward organizational change is an employee's overall positive or negative evaluative judgment of a change initiative implemented by their organization. According to Guimaraes (1996), employee's attitude includes characteristics such as interest in the job, working without constant supervision, taking a positive dimension of things; and employee's willingness to contribute (Feldmann and Teuteberg, 2020). A negative attitude will result in a poor performance, while a positive attitude will yield a distinguished performance and productivity by an employee (Harrell-Cook et al., 2017), which in turn will be beneficial to the organization. Therefore, employee's attitude is a vehicle to reach the intended success of an organization (Andrew, 2017). Today, organizations have become increasingly aware about the extraordinary significance of their employees' attitude. Thus, they are investing more money, time, and effort than before to create as much positive attitudes as possible among their employees (DeCenzo et al., 2016).

\subsection{Sustainability Performance}

Since the term "sustainability" first appeared in the literature over 20 years ago, numerous academics and practitioners have proposed multiple definitions of this term according to the nature of business and economic sector in which organizations are operating. The World Commission on Environment and Development (WCED) Brundtland Commission defined sustainability as "using resources to meet the needs of the present without compromising the ability of future generations to meet their own needs" (WCED, 1987). One of the most accepted and worldwide used definitions of the term sustainability is the definition introduced by the United States Environmental Protection Agency (EPA), which states that sustainability is "the satisfaction of the economic, social, and security needs of the population in the present and in the future without compromising the natural resource base and environmental quality on which life depends". From a corporate point of view, this definition asserts not only a focus on economic aspects of companies, but also a need to focus on the sustainment of nature's resources and the 
societies they serve. That is why there are more than one nomenclature and synonym to the term sustainability, including triple bottom line (TBL or 3BL), profit-people-planet (3Ps), economics-environment-equity (3E's), corporate social responsibility (CSR), and corporate citizenship (Winter and Knemeyer, 2013; Sharabati, 2018). Although different authors defined these phrases in different ways, it seems that there is a consensus among them about economic dimension, social dimension, and environmental dimension, that are common elements of theses phrases. While economic dimension is a traditional element and its measurements are well agreed-upon, social dimension and environmental dimension are new elements that are less prevalent and much more difficult to measure. The main question in sustainability literature is how to protect the environment and society without sacrificing the economy. These three dimensions are explained in more detail in the following subsections.

\subsubsection{Economic Dimension (ECD)}

Economic dimension addresses the economic needs of any entity that supplies the capital for producing products and services or relies on the company for wages or rewards such as shareholders, employees, customers, business partners, and financial institutions (Krajewski et al., 2019). The long-term success and competitiveness of a company is the basis of the economic dimension (Winter and Knemeyer, 2013). According to Roberts and Tribe (2008), economic dimension is primarily about the ability of a business organization to make a profit and to do business on a sustained basis to survive and support local and national economies. In contrast to social dimension and environmental dimension, economic dimension is principally quantitative in nature and focused on the efficient use of resources and achieving a return on investment.

\subsubsection{Social Dimension (SOD)}

Social dimension addresses the moral, ethical, and charitable expectations that society get from the company (Krajewski et al., 2019). Social dimension is bipolar, as it refers to both individuals and organizations (Winter and Knemeyer, 2013). Although, social dimension is basically based on material conditions, it is immaterial and hard to measure (Lehtonen, 2004). Hall and Matos (2010) asserted that social dimension of sustainability is emerging as the key challenge in sustainable organizations, due to the fact that organizations have to fasten a wide range of partners with different goals, demands, and opinions that may understand the same situation differently. Social dimension in terms of employee health and safety systems boosts employee well-being (Pagell and Gobeli, 2009).

\subsubsection{Environmental Dimension (END)}

Environmental dimension addresses the ecological needs of the planet and the company's supervision of the natural resources used in producing products and services (Krajewski et al., 2019). Environmental dimension incorporates the set of objectives, plans, and mechanisms that promote ecological obligation and energize the development and dissemination of naturally friendly technologies (Klassen, 2001). Achieving environmental dimension includes designing eco-friendly products (Hammouri et al., 2009; Bi et al., 2020), reusing, recycling, and remanufacturing materials, components, and returned products (Sarkis et al., 2010).

\section{Hypotheses Development and the Research Model}

In the following subsections, we discuss each construct and develop the hypotheses on how they are related.

\subsection{The Role of Employee's Attitude Toward the Implementation of Sustainability Policy}

Traditionally, researchers, scholars, and practitioners have considered employee attitude as a critical factor in successful change efforts in organizations (Yousef, 2000; Bernerth, 2004; Bellou, 2007; Khatoon and Farooq, 2015; Zakaria and Abdullah, 2018). Lee and Ha-Brookshire (2018) found that the role of employees on the organization's overall sustainability performance is highly important. Lacy et al. (2009) argued that organizations must invest in helping employees acquire and build the knowledge, skills, and attitudes required to carry out sustainability-related initiatives. Carmeli et al. (2017) found that organizational ethic of care helps shaping employees' positive attitudes through providing higher levels of identification with the organization and effective reaction towards the organizational sustainability, and these mechanisms foster them to be more involved in sustainability-related activities. In more detail, some scholarly works revealed that socio-cultural sustainability is changing strongly and analogously according to the human behavior changes (Mason, 2003; Roberts and Tribe, 2008; Lynch, 2019). Jackson et al. (2012) argued that human resource management efforts play a pivotal role in environmental sustainability initiatives.

Capitalizing on the previous discussion, it is hypothesized that:

$H_{1}$. EAIS positively and significantly affects economic dimension

$H_{2}$. EAIS positively and significantly affects social dimension 
$H_{3}$. EAIS positively and significantly affects environmental dimension

\subsection{The Role of Employee's Attitude Toward the Expansion of Sustainability Policy}

Researchers, scholars, and practitioners have argued that employee attitude toward expanding the sustainability policy is a critical factor in the organizational sustainability performance. For example, Andrew (2017) argued that individual's attitudes, beliefs, and behaviors can affect the intended organizational change as he explained, "employees in organization may contribute toward the achievement of the organization's objective and its efforts for development at varying scale depending on how he/she perceive" (p. 2). The role of employees should not be neglected in supporting businesses' efforts to improve sustainability performance (Lee and Ha-Brookshire, 2018).

Hence, the following hypotheses are developed:

$H_{4}$. EAES positively and significantly affects economic dimension

$H_{5}$. EAES positively and significantly affects social dimension

$H_{6}$. EAES positively and significantly affects environmental dimension

\subsection{The Research Model}

A proposed research model that combines all of the aforementioned hypotheses is shown in Figure 1. The model includes the employee's attitude variable with its sub-variables, namely EAIS and EAES (i.e., independent variables), and sustainability variable with its sub-variables, namely economic dimension, social dimension, and environmental dimension (i.e., dependent variables). Additionally, this model proposes that employee's attitude will have a positive relationship with sustainability. Likewise, each employee's attitude sub-variable will have a positive relationship with sustainability represented by hypotheses from $H_{1}$ to $\mathrm{H}_{6}$ respectively.

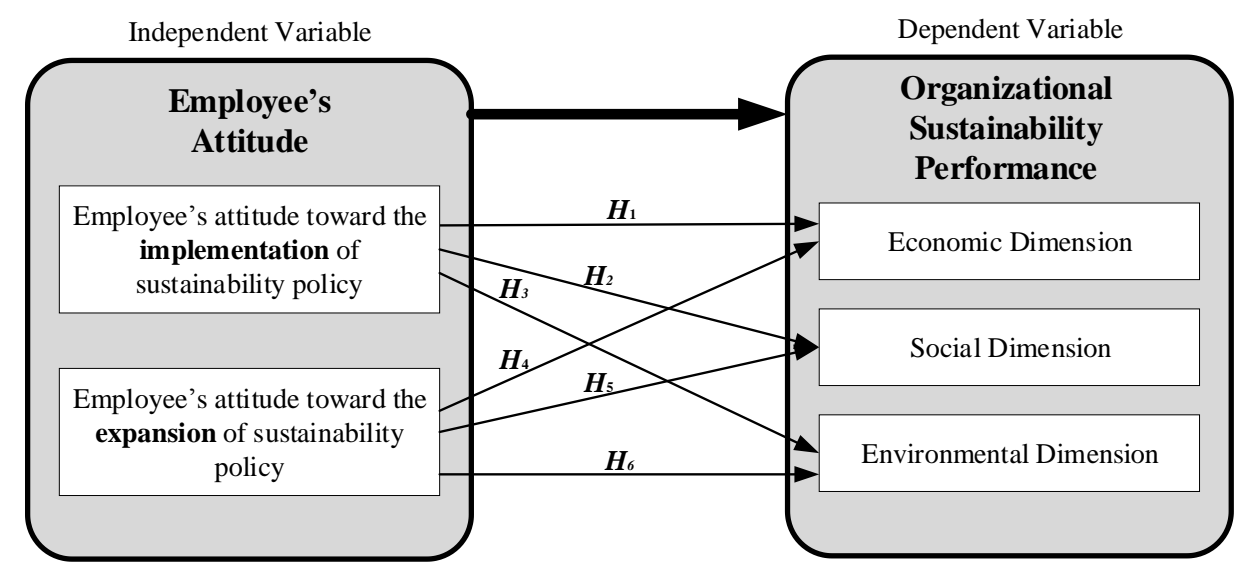

Figure 1. The research model

Sources: Blok et al. 2015; Khatoon and Farooq, 2015; Chang et al. 2018

\section{Methodology}

This scholarly work is a cross-sectional cause-and-effect study. It aims to study the effect of employee's attitude on sustainability of Jordanian banks. In order to achieve this objective, a research instrument was developed, data were collected, and detailed statistical analyses were carried out. These stages are presented in the following subsections.

\subsection{Research Instrument}

Based on the literature review, relevant questionnaire items were drafted in order to measure the construct latent variables of the research model. To improve understanding of its content, the resulting draft was reviewed by 15 academic professors in the field of business administration, as well as five executive managers from different banks in Jordan. Then, some modifications were made according to their notes and recommendations. It is worth mentioning that the items were ensured to be written in such a way that reduces the likelihood of misunderstanding the employee's attitude by the respondent. In its final form, the questionnaire comprised two main sections; the first section included questions about respondent's demographic characteristics (i.e., gender, age, academic qualification, 
years of experience, managerial position, and department), while the second section of the questionnaire contained 30 follow-on accurate and specific items about the implementation of each variable. The respondents were asked to evaluate each item using five-point Likert scale anchored from $1=$ 'not adopted' to $5=$ 'fully adopted' and centered at $3=$ 'partially adopted'. The finished questionnaire items are shown in the Appendix.

\subsection{Research Population and Sample}

In Jordan, there are 24 banks operating, 15 are listed on the Amman Stock Exchange (ABJ, 2020). All of these banks were targeted for data collection, so a comprehensive survey method was used, eliminating the need for sampling. The survey unit consists of 110 employees working in the head office of these banks in Amman. To test the questionnaire items for their clarity, comprehensiveness, and acceptability, a pretest pilot study was conducted before distributing the questionnaire to the targeted banks. After finalizing the pilot study and the distributing the questionnaire to all of them, a total of 98 responses were received. Only 84 responses were valid for further analysis, making a response rate of $85.7 \%$. This high response rate is due to distributing the questionnaire by hand (Harris et al., 1979). The authors of this study administrated and aggressively followed up the questionnaire distribution process themselves. Their involvement contributed to the delivery of the questionnaire to as many respondents as possible and helped in clarifying any ambiguity concerning the definitions or any other issues related to the questionnaire. This response rate is also in line with previous empirical studies conducted in Jordan that used a similar distribution methodology (e.g., Bwaliez, 2012; Al-Tahat and Bwaliez, 2015, Bwaliez, 2018; Bwaliez and Abushaikha, 2019). Thereafter, the data from these questionnaires were coded against the statistical packages for the social sciences (SPSS).

\subsection{Demographic Analysis}

Table 1 shows a description of the demographic characteristics of respondents. Many facts about the respondents can be derived from Table 1 . Unlike males who represent $58.3 \%$ of the respondents, females represent $41.7 \%$ only. Regarding age, it is clear that most respondents' ages are between $21-40$ years old with a percentage of $84.5 \%$. For academic qualification, most of respondents hold bachelor degree with $64.3 \%$, while $17.9 \%$ of respondents hold diploma degree. Fortunately, $15.4 \%$ of employees participated in the questionnaire had more than 15 years of experience which will lead to enrich this study by providing more accurate and real data. Finally, more than half of respondents were single while $48.8 \%$ were married.

Table 1. Demographic analysis $(n=84$ respondents)

\begin{tabular}{rrr}
\hline Category & Frequency & Percentage \\
Gender & & \\
\hline Male & 49 & 58.3 \\
\hline Female & 35 & 41.7 \\
\hline Total & 84 & 100.0 \\
\hline Age & & \\
\hline$<21$ years & 1 & 1.2 \\
\hline Between 21-30 years & 34 & 40.5 \\
\hline Between 31-40 years & 37 & 44.0 \\
\hline Between 41-50 years & 9 & 10.7 \\
\hline$>50$ years & 3 & 3.6 \\
\hline Total & 84 & 100.0 \\
\hline Academic qualification & 3 & 3.6 \\
\hline Secondary school & 15 & 17.9 \\
\hline Diploma & 5 & 6 \\
\hline High diploma & 54 & 64.3 \\
\hline Bachelor & 1 & 1.2 \\
\hline Master & &
\end{tabular}




\begin{tabular}{rrr}
\hline Doctorate & 0 & 0 \\
\hline Total & 84 & 100.0 \\
\hline Years of experience & & \\
\hline Less than 5 years & 21 & 25.0 \\
\hline Between 5-9 years & 25 & 29.8 \\
\hline Between 10-15 years & 25 & 29.8 \\
\hline$>15$ years & 13 & 15.4 \\
\hline Total & 84 & 100.0 \\
\hline Marital status & & 51.2 \\
\hline Single & 43 & 48.8 \\
\hline Married & 41 & 100.0 \\
\hline Total & 84 &
\end{tabular}

\subsection{Instrument's Validity and Reliability}

Validity of the research instrument can be confirmed by ensuring content, face, and construct validity (Sharabati, 2018). To ensure content validity of the research instrument, questionnaire items were drafted based on multiple sources of data (i.e., different scholarly works presented in the aforementioned literature review). To ensure face validity, the resulting draft was reviewed by 15 academic professors in the field of business administration, as well as five executive managers from different banks in Jordan. Thereafter, some modifications were made according to their notes and recommendations in order to improve understanding of the questionnaire's content. Consequently, research instrument's validity was assumed. Finally, to ensure construct validity, principal component factor analysis, Kaiser-Meyer-Olkin (KMO) test was used. Factor analysis refers to the explanatory and conformity of data. Factor loading more than 0.5 is good and accepted (Hair et al., 2010; Hair et al., 2014). KMO value between 0.80 and 1 refers to high adequacy, and a value more than 0.60 is accepted. Table 3 shows that factor 1 value for all variables is ranging between 0.670 and 0.740 , which indicates that all variables are matching together and have strong explanatory and conformity power. Table 3 also shows that all KMO values are more than 0.6 , which indicates an acceptable adequacy of sampling.

Reliability includes internal consistency of the construct latent variables (Bwaliez, 2012; Al-Tahat and Bwaliez, 2015; Bwaliez, 2018). It is measured using the Cronbach's alpha $(\alpha)$ coefficient, a popular measure of the degree to which different questionnaire items complement each other and measure the same concept (Litwin, 1995). According to many scholars (e.g., Hair et al., 2010; Sekaran and Bougie, 2010; Hair et al., 2014), Cronbach's $\alpha$ value more than 0.70 ensures good reliability of the research instrument. Table 3 shows that Cronbach's $\alpha$ values for all variables are accepted, where they are ranging between 0.788 and 0.957 . This indicates acceptable internal consistency of the research instrument.

Table 2. Validity and reliability tests

\begin{tabular}{rrrrr}
\hline \multirow{2}{*}{ Variable } & \multicolumn{3}{c}{ Validity test } & Reliability test \\
\cline { 2 - 5 } & Factor 1 loading value & KMO value & No. of items & Cronbach's $\boldsymbol{\alpha}$ value \\
\hline EAIS & 0.737 & 0.726 & 6 & 0.788 \\
\hline EAES & 0.740 & 0.701 & 6 & 0.875 \\
\hline ECD & 0.670 & 0.801 & 6 & 0.908 \\
\hline SOD & 0.681 & 0.839 & 6 & 0.957 \\
\hline END & 0.670 & 0.713 & 6 & 0.883 \\
\hline
\end{tabular}




\section{Results}

A detailed statistical analysis was carried out using the SPSS software. Analysis comprises bivariate Pearson correlation, multiple linear regression, and hypotheses testing.

\subsection{Relationships Between Variables}

To examine the relationships between the variables of the research model, correlation analysis was conducted between the mean of answers for each questionnaire item. Table 4 shows the bivariate Pearson's correlation matrix for all of these variables. The relationship between employee's attitude variables is medium, where the coefficient of correlation $(r)$ value is 0.647 , while the relationships between sustainability variables are weak, since $r$ values are ranging between 0.352 and 0.461 . By looking to $r$ values between each employee's attitude variable and sustainability variables, we can conclude that the relationships between them are weak to medium. EAIS has the highest effect on environmental dimension $(r=0.471)$, followed by economic dimension $(r=0.428)$, then social dimension $(r=0.371)$, while EAES has the highest effect on environmental dimension $(r=0.511)$, followed by economic dimension $(r=0.417)$, then social dimension $(r=0.375)$. It is also worth mentioning that all of these correlations are significant at the 0.01 level of significance.

Table 3. Bivariate Pearson's correlation test

\begin{tabular}{rrrrrr}
\hline & EAIS & EAES & ECD & SOD & END \\
\hline EAIS & 1 & & & & \\
\hline EAES & $0.647^{* *}$ & 1 & & & \\
\hline ECD & $0.428^{* *}$ & $0.417^{* *}$ & 1 & & \\
\hline SOD & $0.371^{* *}$ & $0.375^{* *}$ & $0.461^{* *}$ & 1 & 1 \\
\hline END & $0.471^{* *}$ & $0.511^{* *}$ & $0.401^{* *}$ & $0.352^{* *}$ & 1 \\
\hline
\end{tabular}

Notes: ${ }^{* *}$ Correlation is significant at the 0.01 level (two-tailed), $n=84$

\subsection{Hypotheses Testing}

Multiple regression was used to test the hypotheses of this study. Table 5 shows that he coefficient of correlation $(r)$ values are varying between 0.317 and 0.511 , which means that there are medium and positive relationships between the two independent variables (EAIS and EAES) and the three dependent variables (ECD, SOD, and END). It also shows that the coefficient of determination $\left(R^{2}\right)$ values are ranging between 0.101 and 0.261 , which means that any change of one unit in the employee's attitudes will produce a change of $10-26 \%$ in the three sustainability dimensions.

The standardized regression coefficient $(\beta)$ value shown in Table 5 is a measure of how strongly each independent variable influences the dependent variable, where a positive $\beta$ value indicates a positive effect while a negative $\beta$ value refers to a negative effect (Berenson et al., 2020). The results ensure that the two independent variables have diversified significant and positive effects on the three dependent variables. In more detail, EAIS has significant and positive impact on the three sustainability dimensions: $\operatorname{ECD}(t=3.620, p<0.01)$, SOD $(t=3.030, p<0.01)$, and $\operatorname{END}(t=4.293, p<0.01)$ at the 0.01 level of significance. These results support the hypotheses $H_{1}, H_{2}$, and $H_{3}$. The highest impact is for EAIS on $\operatorname{SOD}(\beta=0.526)$, followed by $\operatorname{END}(\beta=0.481)$, then $\operatorname{ECD}(\beta=0.385)$. On the other hand, EAES has significant and positive impact on the three sustainability dimensions: $\operatorname{ECD}(t=5.379, p<0.01)$, $\operatorname{SOD}(t=3.464, p<0.01)$, and $\operatorname{END}(t=4.151, p<0.01)$ at the 0.01 level of significance. These results support the hypotheses $H_{4}, H_{5}$, and $H_{6}$. The highest impact is for EAES on SOD $(\beta=0.593)$, followed by ECD $(\beta=0.531)$, then $\operatorname{END}(\beta=0.468)$. 
Table 4. Summary of the hypotheses testing results

\begin{tabular}{rrrrrrrrr}
\hline Hypothesis & Relationship & $\boldsymbol{r}$ & $\boldsymbol{R}^{\mathbf{2}}$ & $\boldsymbol{B}$ & $\boldsymbol{t}$ & Sig. & $\begin{array}{c}\text { Support of } \\
\text { hypothesis }\end{array}$ & Implication \\
\hline$H_{1}$ & EAIS $\rightarrow$ ECD & 0.371 & 0.138 & 0.385 & 3.620 & 0.001 & Supported & EAIS affects ECD \\
\hline$H_{2}$ & EAIS $\rightarrow$ SOD & 0.317 & 0.101 & 0.526 & 3.030 & 0.003 & Supported & EAIS affects SOD \\
\hline$H_{3}$ & EAIS $\rightarrow$ END & 0.428 & 0.184 & 0.481 & 4.293 & 0.000 & Supported & EAIS affects END \\
\hline$H_{4}$ & EAES $\rightarrow$ ECD & 0.511 & 0.261 & 0.531 & 5.379 & 0.000 & Supported & EAES affects ECD \\
\hline$H_{5}$ & EAES $\rightarrow$ SOD & 0.357 & 0.128 & 0.593 & 3.464 & 0.001 & Supported & EAES affects SOD \\
\hline$H_{6}$ & EAES $\rightarrow$ END & 0.417 & 0.174 & 0.468 & 4.151 & 0.000 & Supported & EAES affects END \\
\hline
\end{tabular}

\section{Conclusions and Implications}

\subsection{Conclusions}

A good employee's performance is an essential element for organizational success, effectiveness, excellence, expansion, and survival. This study confirmed that employee's attitude is one of the most important factors that directly affect the organizational sustainability performance. In literature, employee's attitude is the main concern of multi field studies that have been executed during the past five decades worldwide. The results of great majority of these studies have confirmed that employee's attitude positively affects the performance and success of any business organization in general and on the implementation of its programs, policies, and strategies in particular (Hobson and Essex, 2001; Harmon and Moolenkamp, 2012; Anitha, 2014; Melián-González, 2016; Inuwa et al., 2017; Smith and Bititci, 2017; Upadhyay and Awasthi, 2020). Furthermore, this study aimed to investigate the role of employee's attitude toward implementing and expanding the sustainability policy in the overall sustainability performance of the organization in terms of economic, social, and environmental dimensions. The results revealed that there is a significant and positive relationship between employee's attitude toward implementing and expanding sustainability policy and the triple bottom lines of the organizational sustainability performance.

\subsection{Practical Implications}

This study promotes the idea of studying the employee's attitude in Jordan's banking sector in order to enhance its sustainability performance. It also recommends these banks to rethink in their efforts toward economic, social, and environmental dimensions.

\section{Limitations and Recommendations}

\subsection{Limitations and Future Research}

Though the current study attained some important findings and insights related to the effect of employee's attitude on sustainability dimensions, it has limitations that can be addressed in future studies. This study was directed toward banking sector in Jordan. However, generalizing the results to other sectors and countries is suspicious. Therefore, the study at hand can be extended to other service and manufacturing industries, as well as it can be carried out in other Arab and international settings and contexts in order to increase the validity and generalizability. Since this study is cross-sectional, a more stringent test of the relationship between employee's attitude and sustainability dimensions requires a longitudinal study, or field experiment, which could involve gathering data over a longer time span. Then, the association between the variation of both independent and dependent variables could be further investigated. This study investigated the direct relationship between employee's attitude and sustainability dimensions. However, future research is needed to investigate the indirect relationship between them through examining the mediating role of several factors.

\subsection{Recommendations for Practitioners}

This study provides a useful reference for policy makers and researchers to understand how sustainability is perceived and implemented by the Jordan's banking sector. It also proposes an employee-focused model that banks and other organizations can exploit as a guideline towards greater sustainability performance. 


\section{References}

Abbasi, M., \& Nilsson, F. (2012). Themes and challenges in making supply chains environmentally sustainable. Supply Chain Management: An International Journal, 17(5), 517-530.

ABJ. (2020). Association of Banks in Jordan. Retrieved January 31, 2020, from https://www.abj.org.jo/Pages/viewpage?pageID=43

Agyemang, O. S., \& Ansong, A. (2017). Corporate social responsibility and firm performance of Ghanian SMEs: mediating role of access to capital and firm reputation. Journal of Global Responsibility, 8(1), 47-62.

Al Qeed, M. (2015). The relationship between corporate social responsibility toward the employees and hotel performance in Jordan. International Business Research, 8(1), 197-202.

Ali, F., \& Sayyed, M. A. (2012). Investigating the influence of employee attitude toward change and leadership style on change readiness by SEM. International Journal of Academic Research in Business and Social Sciences, 2(11).

Al-Tahat, M. D., \& Bwaliez, O. M. (2015). Lean-based workforce management in Jordanian manufacturing firms. International Journal of Lean Enterprise Research, 1(3), 284-316.

Andrew, A. (2017). Influence of employee attitude on employee readiness for organizational change. Asian Journal of Economics, Business, and Accounting, 5(1), 1-11.

Anitha, J. (2014). Determinants of employee engagement and their impact on employee performance. International Journal of Productivity and Performance Management, 63(3), 308-323.

Bellou, V. (2007). Psychological contract assessment after a major organizational change: the case of mergers and acquisitions. Employee Relations, 29(1), 68-88.

Berenson, M. L., Levine, D. M., Szabat, K. A., \& Stephan, D. F. (2020). Basic Business Statistics: Concepts and Applications (14th ed.). Pearson Education Ltd., Harlow, UK.

Bernerth, J. (2004). Expanding our understanding of the change message. Human Resource Development Review, $3(1), 36-52$.

Bhatta, N. M. K., Bhavanishankar, S., \& Chandrashekar, D. (2020). Do Green Initiatives Make Business Sense? The Indian Case. International Journal of Innovation and Technology Management (IJITM), 17(3), 1-24.

Bi, K., An, K., \& Li, X. (2020). A Resource Optimization Allocation Strategy for China's Shipbuilding Industry Green Innovation System. International Journal of Innovation and Technology Management, 17(4), 2050029. https://doi.org/10.1142/S0219877020500297

Blok, V., Wesselink, R., Studynka, O., \& Kemp, R. (2015). Encouraging sustainability in the workplace: a survey on the pro-environmental behavior of university employees. Journal of Cleaner Production, 106, 55-67.

Bohner, G., \& Dickel, N. (2011). Attitudes and attitude change. Annual Review of Psychology, 62, 391-417.

Brömer, J., Brandenburg, M., \& Gold, S. (2019). Transforming chemical supply chains toward sustainability - A practice-based view. Journal of Cleaner Production, 236, 117701. https://doi.org/10.1016/j.jclepro.2019.117701

Bwaliez, O. M. (2012). Design and analysis of lean-based workforce management system in Jordanian industries. Master Thesis, The University of Jordan, Amman, Jordan.

Bwaliez, O. M. (2018). Applying the lean philosophy in the field of workforce management: a case study from Jordanian service sector. Proceedings of the Istanbul 58th International Conference on 'Business, Economics, Social Science \& Humanities', Academic Fora (Vol. 1, No. 3, May 5-6, 2018), Istanbul, Turkey.

Bwaliez, O. M., \& Abushaikha, I. (2019). Integrating the SRM and lean paradigms: the constructs and measurements. Theoretical Economics Letters, 9(7), 2371-2396.

Carmeli, A., Brammer, S., Gomes, E., \& Tarba, S. Y. (2017). An organizational ethic of care and employee involvement in sustainability-related behaviors: a social identity perspective. Journal of Organizational Behavior, 38(9), 1380-1395.

Chang, R. D., Zuo, J., Zhao, Z. Y., Soebarto, V., Lu, Y., Zillante, G., ... Gan, X. L. (2018). Sustainability attitude and performance of construction enterprises: a China study. Journal of Cleaner Production, 172, $1440-1451$. 
DeCenzo, D. A., Robbins, S. P., \& Verhulst, S. L. (2016). Fundamentals of Human Resource Management. John Wiley \& Sons.

Elias, S. M. (2009). Employee commitment in times of change: assessing the importance of attitudes toward organizational change. Journal of Management, 35(1), 37-55.

Farooq, O., Farooq, M., \& Reynaud, E. (2019). Does employees' participation in decision making increase the level of corporate social and environmental sustainability? An investigation in South Asia. Sustainability, 11(2), 511.

Fatma, M., Rahman, Z., \& Khan, I. (2015). Building company reputation and brand equity through CSR: the mediating role of trust. International Journal of Bank Marketing, 33(6), 840-856.

Feldmann, A., \& Teuteberg, F. (2020). Understanding the Factors Affecting Employees' Motivation to Engage in Co-Creation in the Banking Industry. International Journal of Innovation and Technology Management (IJITM), $17(2), 1-21$.

Guimaraes, T. (1996). TQM's impact on employee attitudes. The TQM Magazine, 8(1), 20-25.

Hammouri, H., Kabore, P., \& Kinnaert, M. (2009). Adopting and applying eco-design techniques: a practitioners perspective. Journal of Cleaner Production, 17(5), 549-558.

Harmon, R. R., \& Moolenkamp, N. (2012). Sustainable IT services: Developing a strategy framework. International $\begin{array}{lllll}\text { Journal of Innovation and Technology Management, } & 9(2), & 1250014 .\end{array}$ https://doi.org/10.1142/S0219877012500149

Harrell-Cook, G., Levitt, K., \& Grimm, J. (2017). From engagement to commitment: a new perspective on the employee attitude-firm performance relationship. International Leadership Journal, 9(1), 3-29.

Harris, J. R., Guffey, H. J., \& Laumer, J. F. (1979). The windshield method of questionnaire distribution: a viable alternative. Journal of the Academy of Marketing Science, 7(3), 184-191.

Hobson, K., \& Essex, S. (2001). Sustainable tourism: a view from accommodation businesses. Service Industries Journal, 21(4), 133-146.

Igbaria, M., Parasuraman, S., \& Badawy, M. K. (1994). Work experience, job involvement, and quality of work life among information system perdonnel. MIS Quarterly, 18(2), 175-191.

Inuwa, M., Mashi, M. S., \& Salisu, I. M. (2017). Job attitude and employee performance: an empirical study of non-academic staff of Bauchi University Gadau Nigeria. International Journal of Business and Management Future, 1(1), 1-13.

Jackson, S. E., Ones, D. S., \& Dilchert, S. (2012). Managing human resources for environmental sustainability. John Wiley \& Sons.

Khatoon, S., \& Farooq, A. (2015). Employees' attitude toward change and organizational performance. Research and Sustainable Business, 347.

Klassen, R. D. (2001). Plant-level environmental management orientation: the influence of management views and plant characteristics. Production and Operations Management, 10(3), 257-275.

Krajewski, L. J., Malhotra, M. K., \& Ritzman, L. P. (2019). Operations Management: Processes and Supply Chains (12th ed.). Pearson Education Ltd., Essex, England.

Kucharska, W., \& Kowalczyk, R. (2019). How to achieve sustainability? Employee's point of view on company's culture and CSR practice. Corporate Social Responsibility and Environmental Management, 26(2), 453-467.

Lacy, P., Arnott, J., \& Lowitt, E. (2009). The challenge of integrating sustainability into talent and organization strategies: investing in the knowledge, skills, and attitudes to achieve high performance. Corporate Governance: The International Journal of Business in Society, 9(4), 484-494.

Lee, S. H., \& Ha-Brookshire, J. (2018). The effect of ethical climate and employee's organizational citizenship behavior on US fashion retail organizations' sustainability performance. Corporate Social Responsibility and Environmental Management, 25(5), 939-947.

Lehtonen, M. (2004). The environmental - social interface of sustainable development: capabilities, social capital, institutions. Ecological Economics, 49(2), 199-214. 
Lynch, R. (2019). Towards an innovation link between dynamic capabilities and sustainability strategy: options for emerging market companies. International Journal of Innovation and Technology Management, $16(4), 1940003$. https://doi.org/10.1142/S0219877019400030

Masa'deh, R., Alrowwad, A., Alkhalafat, F., Obeidat, B., \& Abualoush, S. (2018). The role of corporate social responsibility in enhancing firm performance from the perspective of IT employees in Jordanian Banking sector: the mediating effect of transformational leadership. Modern Applied Science, 12(7), 1-26.

Mason, P. (2003). Tourism Impacts, Planning, and Management. Oxford, Butterworth-Heinemann.

Melián-González, S. (2016). An extended model of the interaction between work-related attitudes and job performance. International Journal of Productivity and Performance Management, 65(1), 42-57.

Merriman, K. K., Sen, S., Felo, A. J., \& Litzky, B. E. (2016). Employees and sustainability: the role of incentives. Journal of Managerial Psychology, 31(4), 820-836.

Obeidat, B. Y. (2016). Exploring the relationship between corporate social responsibility, employee engagement, and organizational performance: the case of Jordanian mobile telecommunication companies. International Journal of Communications, Network and System Sciences, 9(9), 361-386.

Pagell, M., \& Gobeli, D. (2009). How plant managers' experiences and attitudes toward sustainability relate to operational performance. Production \& Operations Management, 18(3), 278-299.

Ray, D. (2020). A global attitude, a global perspective, a global pledge towards sustainability: an approach of understanding. International Journal on Recent Trends in Business and Tourism, 4(1), 34-37.

Roberts, S., \& Tribe, J. (2008). Sustainability indicators for small tourism enterprises - An exploratory perspective. Journal of Sustainable Tourism, 16(5), 575-594.

Sarkis, J., Gonzalez-Torre, P., \& Adenso-Diaz, B. (2010). Stakeholder pressure and the adoption of environmental practices: the mediating effect of training. Journal of Operations Management, 28(2), 163-176.

Schaltegger, S. (2011). Sustainability as a Driver for Corporate Economic Success. Consequences for the Development of Sustainability Management Control. Society and Economy, 33(1), 15-28.

Schaltegger, S., Windolph, S. E., \& Herzig, C. (2012). Applying the known: a longitudinal analysis of the knowledge and application of sustainability management tools in large German companies. Society and Economy, 34(4), 549-579.

Sharabati, A. A. (2018). Effect of corporate social responsibility on Jordan pharmaceutical industry's business performance. Social Responsibility Journal, 14(3), 566-583.

Shin, J., Kim, C., \& Yang, H. (2018). The effect of sustainability as innovation objectives on innovation efficiency. Sustainability, 10(6), 1966. https://doi.org/10.3390/su10061966

Smith, M., \& Bititci, U. S. (2017). Interplay between performance measurement and management, employee engagement, and performance. International Journal of Operations \& Production Management, 37(9), 1207-1228.

Upadhyay, T., \& Awasthi, M. (2020). Understanding the role of job satisfaction for an employee in terms of job performance. Our Heritage, 68(1), 6426-6434.

WCED. (1987). World Commission on Environment and Development, Our Common Future (The Brundtland report). Oxford University Press, Oxford.

Winter, M., \& Knemeyer, A. M. (2013). Exploring the integration of sustainability and supply chain management: current state and opportunities for future inquiry. International Journal of Physical Distribution \& Logistics Management, 43(1), 18-38.

Yousef, D. A. (2000). Organizational commitment and job satisfaction as predictors of attitudes towards organizational change in a non-western setting. Personnel Review, 20(5), 567-592.

Zakaria, A., \& Abdullah, H. H. (2018). Attitudes towards change and organizational performance: a conceptual discussion. Journal of Technology and Operations Management, 13(1), 10-17. 


\section{Appendix}

Questionnaire

Kindly indicate the degree of implementation of each of the following practices in your bank (Use the rating scale from 1 = "the lowest implementation" to $5=$ "the highest implementation").

Employee's attitude toward implementing sustainability policy (EAIS)

EAIS1: The bank believes that sustainability can enhance its overall performance.

EAIS2: The bank considers sustainability as a strategic choice.

EAIS3: All bank's resources are used to ensure achieving balanced economic, social, and environmental needs.

EAIS4: Bank's activities do not have negative economic effects on the national economy.

EAIS5: Bank's activities do not have negative cultural and social effects on society.

EAIS6: Bank's activities do not have negative effects on the environment.

\section{Employee's attitude toward expanding sustainability policy (EAES)}

EAES1: The bank adopts a responsible policy for the development of sustainability in the sector in which it operates.

EAIS2: The bank works on developing sustainability policy and plan as it help in expanding the bank's activities in the future.

EAES3: The bank seeks to support investments and projects that aim to develop natural resources.

EAES4: More laws and regulations should be issued to introduce effective standards for banking activities.

EAES5: Voluntary initiatives are the best to promote sustainability in banks.

EAES6: The bank would take appropriate measures to contribute in developing the banking sector policies.

\section{Economic dimension (ECD)}

ECD1: The bank fulfills all due tax payments.

ECD2: The bank contributes to an increased gross domestic product (GDP) of the Jordanian economy.

ECD3: The bank contributes to reduce unemployment rate through providing training and job opportunities.

ECD4: The bank attracts foreign investments to support the national economy.

ECD5: The bank generates foreign currency to the country.

ECD6: The bank diversifies its products offered in the market.

\section{Social dimension (SOD)}

SOD1: The bank provides health insurance plan to the current and retired employees and their families.

SOD2: The bank applies a fair system.

SOD3: The bank supports the higher education for employees and their children.

SOD4: The bank provides training centers for local community members.

SOD5: The bank cooperates with the universities for scientific research purposes.

SOD6: The bank applies the occupational health and safety system for the employees.

\section{Environmental dimension (END)}

END1: The bank adopts an environmental management system.

END2: The bank controls noise and light pollution.

END3: The bank uses eco-friendly sources of energy.

END4: The bank grows trees to increase the vegetation.

END5: The bank adheres to domestic and international regulations as to protect the environment.

END6: The bank holds training sessions for employees regarding environmental issues.

\section{Copyrights}

Copyright for this article is retained by the author(s), with first publication rights granted to the journal.

This is an open-access article distributed under the terms and conditions of the Creative Commons Attribution license (http://creativecommons.org/licenses/by/4.0/). 